\title{
IMPLEMENTASI WHITE BOX PADA INFORMASI AKADEMIK SMP NEGERI 1 BUPON
}

\author{
Solmin Paembonan ${ }^{1)}$ \\ ${ }^{1)}$ Dosen Program Studi Teknik Informatika, Universitas Andi Djemma, Palopo. \\ 1) solmin.p@gmail.com
}

\begin{abstract}
Abstrak
Penelitian ini bertujuan untuk menghasilkan informasi akademik yang mampu mengatasi kelemahankelemahan dari sistem yang sedang dipakai saat ini. Sistem akademik yang sedang berjalan di SMP NEGERI 1 BUPON masih menggunakan ms.office, tanpa adanya database. Hal ini dapat diliat dari cara pembuatan laporan data siswa, staf dan guru. Waterfall pada desain akademik SMP Negeri I BUPON ini melakukan pendekatan secara urut mulai dari level kebutuhan sistem lalu menuju ke tahap analisis, desain, coding, testing dan maintenance, dimana tahap demi tahap dilalui harus menunggu selesainya tahap sebelumnya dan berjalan berurutan. Selanjutnya hasil pengujian dengan metode pengujian white box bernilai sama untuk jumlah Region $=71$, Cyclomatic Complexity $=71$ dan Independent Path $=71$.
\end{abstract}

Kata kunci: Waterfall, Akademik, White Box

\section{PENDAHULUAN}

Mencermati perkembangan teknologi informasi yang sedemikian pesatnya adalah wacana hangat yang menjadi perbincangan dunia saat ini. Penggunaan Personal Komputer (PC) yang sangat membantu dalam pemrosesan data untuk melahirkan suatu informasi menjadi suatu hal yang sangat dibutuhkan oleh setiap instansi yang ada saat ini, baik itu instansi pemerintah, swasta dan sekolah ataupun yayasan pendidikan yang memiliki tingkat persaingan yang sangat ketat. Dengan keunggulan teknologi informasi ini, semua kebutuhan pemakai dapat ditangani secara lebih cepat, mudah dan tepat.

Dalam kegiatan sekolah tidak lepas dari data-data yang dapat berubah sewaktuwaktu dan dalam jumlah data yang sangat besar. Perubahan data tersebut harus tersimpan dengan baik. Dalam pengelolaan data, kebanyakan sekolah menggunakan sistem pemrosesan manual, yaitu data yang ada berupa setumpuk kertas atau rekaman yang disimpan dalam rak berkas. Masalah yang sering timbul dalam pengolahan data siswa pada SMP Negeri I BUPON adalah keterlambatan dan kerumitan yang disebabkan oleh semua kegiatan masih menggunakan aplikasi yang tidak berbasis database pengolahan data masih menggunakan Microsoft Word dan Microsoft Excel.

Desain yang dirancang akan mengintegrasikan data kesiswaan dalam satu basisdata sehingga memudahkan proses pengaturan, penilaian dan pengelompokan data. Desain yang dirancang untuk memproses laporan kesiswaan yaitu data siswa, data kelas, mata pelajaran dan nilai siswa akan lebih memudahkan operator pada saat melaksanakan tugasnya, maka operator hanya menginputkan stambuk siswa untuk mengetahui data-datanya keseluruhan. Desain informasi akademik pada SMP Negeri I BUPON akan memperlancar proses pembuatan laporan data siswa, staf dan guru serta diharapkan semua kendala-kendala dalam mengolah data dapat diatasi dengan mudah, sehingga informasi yang dihasilkan dapat berjalan sesuai yang diinginkan. Dalam penelitian ini menggunakan metode waterfall untuk menganalisa akan kebutuhan user hingga memelihara fitur-fitur yang dimiliki oleh desain informasi akademik SMP Negeri I BUPON. Pada penelitian Hartono (2018) juga ditunjukkan bahwa 
pemanfaatan teknologi informasi dan komunikasi pada SMP Negeri 2 Palopo dilakukan secara maksimal maka perlu diadakannya sebuah sistem informasi yang mengelola data data perpustakaan, untuk merancangan sistem informasi perpustkaan pada SMP Negeri 2 Palopo digunakan model waterfall. Metode pengujian yang digunakan dalam penilitian ini adalah metode pengujian langsung dengan menggunakan teknik uji coba white box Testing. Dimana teknik pengujian ini merupakan pengujian terhadap cara kerja perangkat lunak itu sendiri yaitu basis path (prosedur programnya) atau proses looping (perulangannya). Teknik pengujian white box adalah teknik perancangan test case yang menggunakan struktur kontrol dan perancangan prosedural untuk mendapatkan test case Pressman (2010). Penelitian mengenai white box dalam berbagai permasalahan cukup banyak dilakukan diantaranya Khan (2011) yakni terhadap teknik pengujian perangkat lunak menggunakan white box testing. White box yang dijelaskan dalam penelitiannya Syaikhuddin (2018) menggunakan proses independent path, menghitung cyclomatic complexity dan graph matrices dalam pengujian white box.

\section{METODOLOGI PENELITIAN \\ Deskripsi Sistem}

Salah satu aktivitas administrasi yang dilakukan di SMP NEGERI 1 BUPON adalah pengolahan informasi data siswa. Data siswa ini merupakan sumber informasi bagi siswa. Untuk mengolah informasi data siswa ini, SMP NEGERI 1 BUPON menggunakan sistem semi komputer (menggunakan Prog. Aplk. Ms. Office). Kekurangan dari pengolah informasi program aplikasi Ms. Office adalah tidak terintegrasinya data, karena data disimpan dalam bentuk file teks, sehingga tidak efisien dalam pengaturan/pengelompokan. Pengolahan informasi data siswa sebaiknya data diintegrasikan dalam suatu sistem basis data dengan merancang sebuah aplikasi pengolah data siswa. Dengan sistem basis data diharapkan SMP NEGERI 1 BUPON dalam pengolahan data siswanya dapat lebih efektif dalam menghasilkan informasi yang akurat. Diharapkan dengan adanya aplikasi pengolahan data siswa ini, akan memudahkan dalam mengolah data untuk menjadi informasi yang tentunya berguna bagi siswa dan juga guru.

\section{Sistem yang Diusulkan}

Adapun diagram alir dokumen sistem yang diusulkan dapat dilihat pada Gambar 1. Sistem komputerisasi ini dirancang sedemikian rupa sehingga memudahkan pihak pengelolah dalam memanajemenkan data-data pengolahan data akademik sehingga menghasilkan output yang cepat dan akurat. Dengan penerapan sistem ini maka kendala-kendala yang dihadapi dapat teratasi antara lain yaitu: (1)Dengan sistem penyimpanan dalam bentuk file database terpusat, selain proses pengarsipannya terorganisir dengan baik, juga proses untuk mengakses atau mencari data lebih cepat dibandingkan dengan cara manual. (2)Pembuatan laporan ke pimpinan dapat dengan cepat tersaji. (3)Manajemen pengarsipan data lebih profesional. 


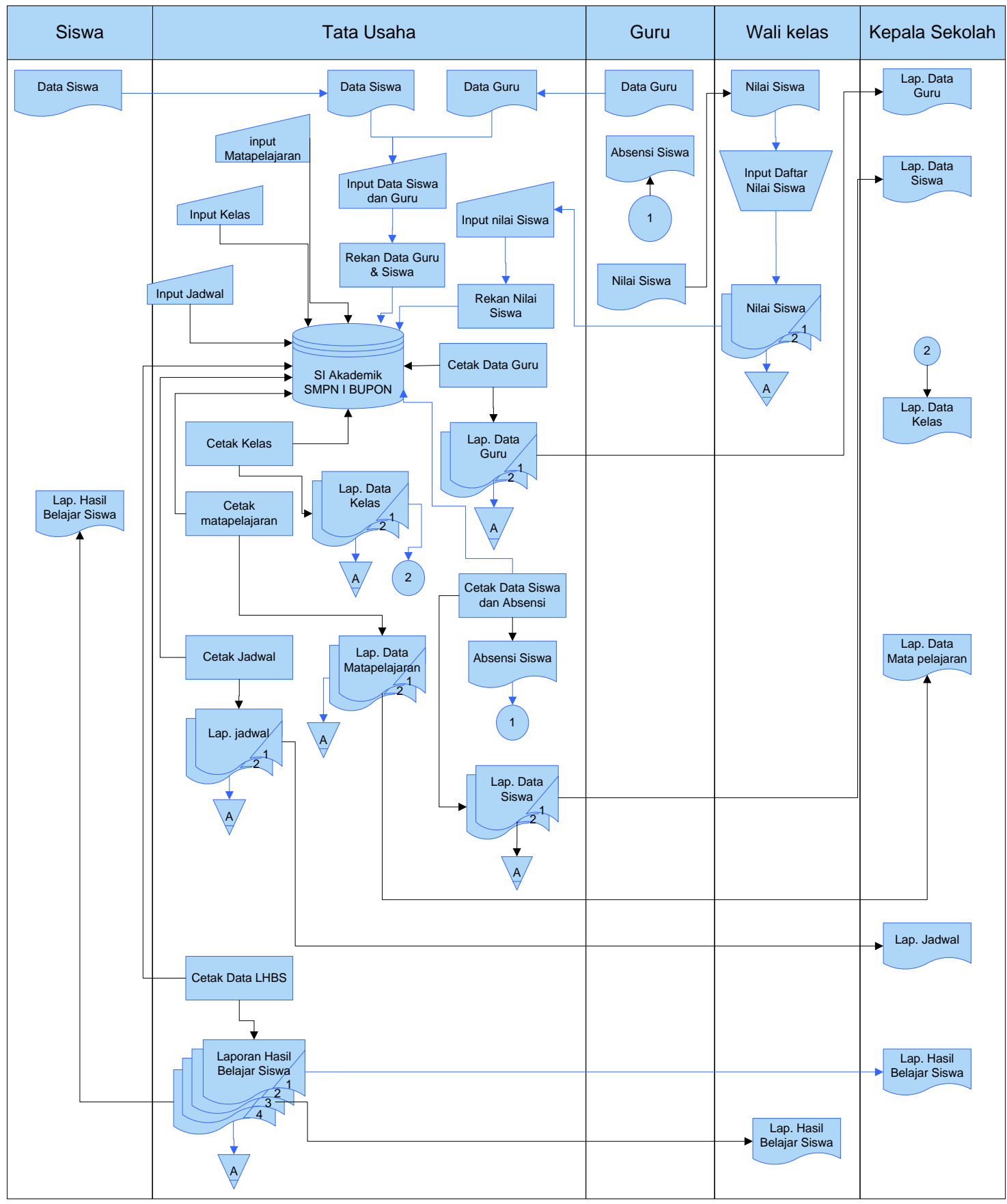

\section{Waterfall}

Gambar 1. Sistem yang Diusulkan

Merupakan metode pengembangan sistem informasi yang sistematik dan sekuensial, Pressman (2010). Metode waterfall memiliki tahapan-tahapan Sommerville (2011) sebagai berikut:

a) Requirments analysis

Layanan sistem, kendala, dan tujuan ditetapkan oleh hasil konsultasi secara rinci dan berfungsi sebagai spesifikasi sistem

b) System dan software design

Tahapan perancangan sistem mengalokasikan kebutuhan-kebutuhan sistem baik perangkat keras maupun perangkat lunak dengan membentuk arsitektur sistem secara 
keseluruhan. Perancangan perangkat lunak melibatkan identifikasi dan penggambaran abstraksi sistem dasar perangkat lunak dan hubungannya.

c) Implementation

Pada tahap ini, perancangan perangkat lunak direalisasikan sebagai serangkain program atau unit program.

d) Integration

Unit-unit individu program atau program digabung dan diuji sebagai sebuah sistem lengkap untuk memastikan apakah sesuai dengan kebutuhan perangkat lunak atau tidak. Setelah pengujian, perangkat lunak dapat dikirimkan ke customer.

e) Maintenance

Pembetulan kesalahan yang tidak ditemukan pada tahapan-tahapan sebelumnya, meningkatkan implementasi dari unit sistem, dan meningkatkan layanan sistem sebagai kebutuhan baru.

\section{White Box}

White box digunakan untuk mendeteksi kesalahan pada kode program Nidhra (2012). White box merupakan metode desain uji kasus yang menggunakan struktur kontrol dari desain prosedural untuk menghasilkan kasus-kasus uji Pressman (2010). Dengan menggunakan metode ujicoba white box, para pengembang software dapat menghasilkan kasus-kasus uji yang ujicoba : (1)Menjamin bahwa seluruh independent paths dalam modul telah dilakukan sedikitnya satu kali, (2)melakukan seluruh keputusan logikal baik dari sisi benar maupun salah, (3)melakukan seluruh perulangan sesuai batasannya dan dalam batasan operasionalnya, dan (4)menguji struktur data internal untuk memastikan validitasnya

\section{Implementasi}

Implementasi pengolahan data pada penelitian ini terdiri dari beberapa halaman. yakni, form menu utama, form input guru, form input mata pelajaran guru dan form data siswa.

a) Form menu utama

Form menu utama pada aplikasi ini dapat dilihat pada Gambar 3.

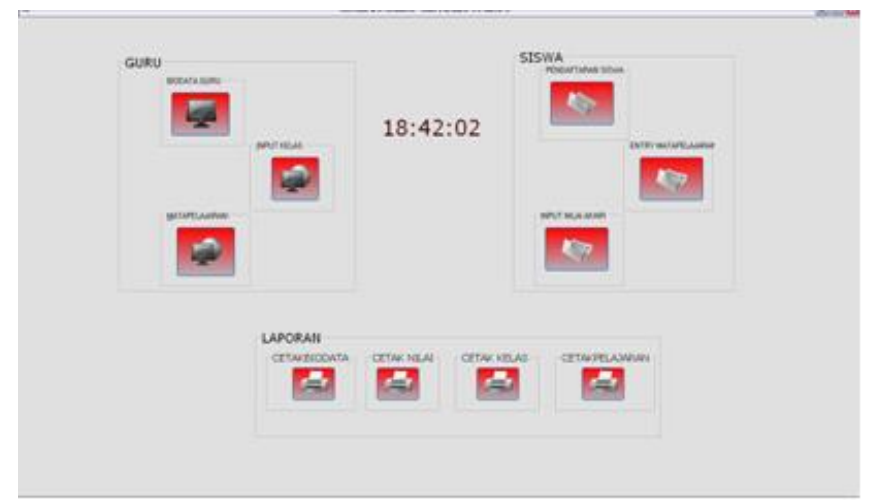

b) Form Input Data Guru

Gambar 2. Form Menu Utama

4.

Tampilan yang digunakan untuk input kontak data pelanggan seperti pada Gambar 


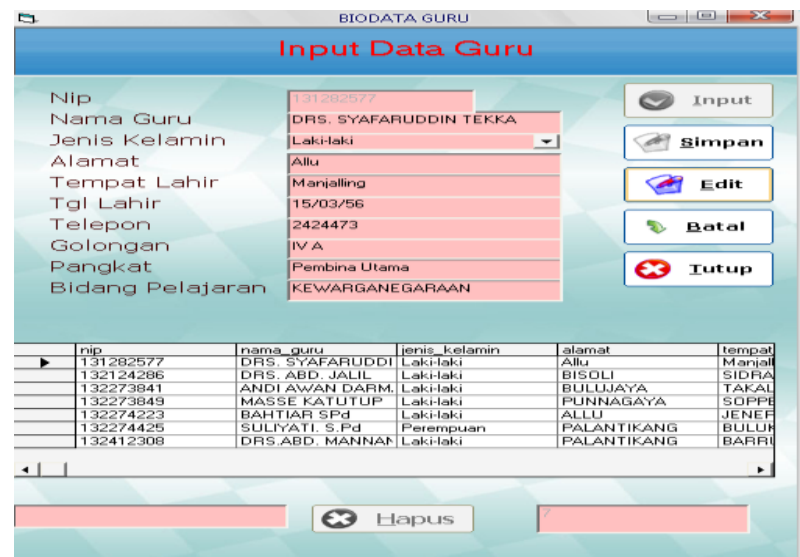

Gambar 3. Form Input Data Guru

c) Form Input Mata Pelajaran Guru

Seperti yang terlihat pada Gambar 5 form ini digunakan untuk menginput mata pelajaran guru.

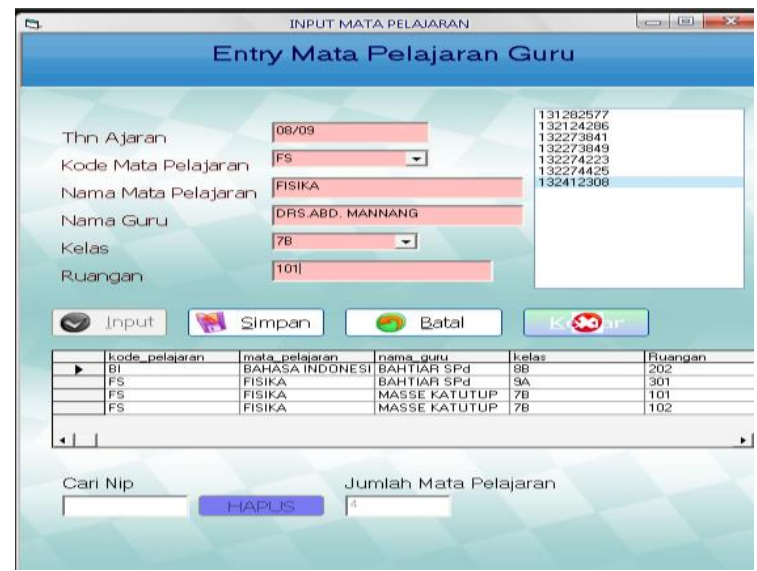

Gambar 4. Form Input Mata Pelajaran Guru

d) Form Input Data Siswa

Form yang digunakan untuk input data siswa pada SMPN 1 BUPON ditunjukkan pada Gambar 6.

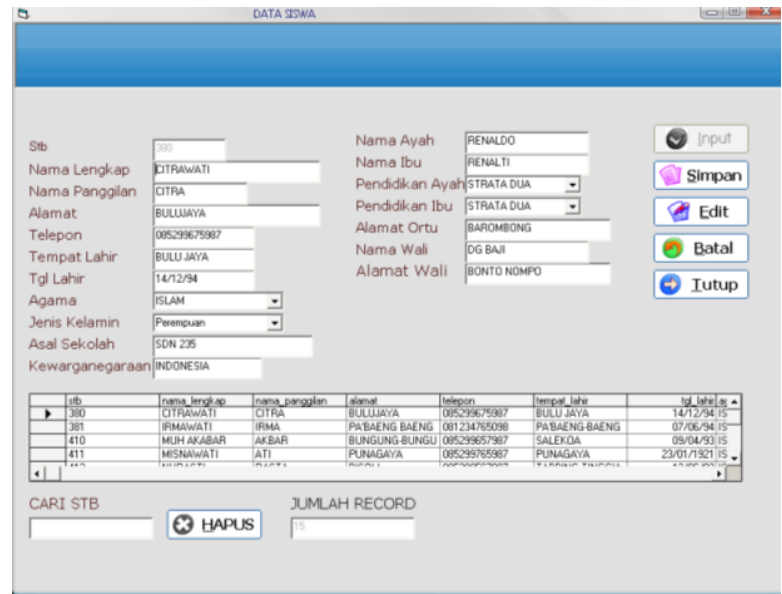

Gambar 5. Form Input Data Siswa 


\section{HASIL DAN PEMBAHASAN}

Pengujian sistem yang dilakukan dengan menggunakan metode pengujian langsung berdasarkan teknik uji white box dapat dihasilkan sistem dan proses perulangan pada flowchart yang membuat sistem berjalan dengan optimal.

Menguji hipotesis menggunakan teknik uji coba white box pada alur program atau kendali program, struktur logika program dan prosedur programnya dengan cara pemetaan flowchart kedalam flowgraph kemudian menghitung besarnya jumlah edge dan node dimana jumlah edge dan node ini akan menentukan besarnya cyclomatic complexity jika: $(1) \mathrm{V}(\mathrm{G})=\mathrm{E}-\mathrm{N}+2$ hasilnya sama dengan $\mathrm{V}(\mathrm{G})=\mathrm{P}+1$ dan (2) Flowgraph mempunyai region yang sama dengan jumlah $\mathrm{V}(\mathrm{G})$

a) Flowgraph Input Data Siswa

Pada Gambar 6 tersaji flowgraph input data siswa, dengan $\mathrm{CC}=7$, Diketahui: $\mathrm{N}=$ $17, \mathrm{E}=22, \mathrm{CC}=\mathrm{E}-\mathrm{N}+2=(22-17)+2=7$

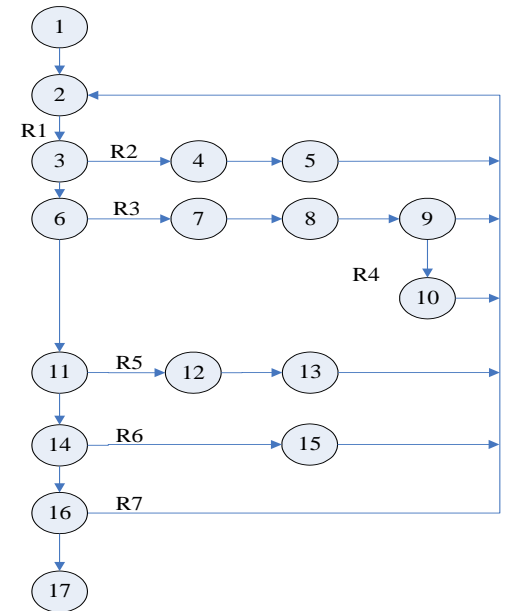

Gambar 6. Flowgraph Input Data Siswa

Hasil pengujian Perancangan Informasi Akademik pada SMP Negei I BUPON tersaji Tabel 1.

Tabel 1. Hasil Pengujian Program

\begin{tabular}{lllll}
\hline No. & Nama Bagan Alir Program & $\begin{array}{l}\text { Jumlah } \\
\text { CC }\end{array}$ & $\begin{array}{l}\text { Independent } \\
\text { Path }\end{array}$ & $\begin{array}{l}\text { Jumlah } \\
\text { Region }\end{array}$ \\
\hline 1. & Form Menu Utama & 15 & 15 & 15 \\
\hline 2. & Form Input Siswa & 7 & 7 & 7 \\
\hline 3. & Form Input Guru & 7 & 7 & 7 \\
\hline 4. & Form Input Mata Pelajaran & 5 & 5 & 5 \\
\hline 5. & Form Input Kelas & 7 & 7 & 7 \\
\hline 6. & Form Input Jadwal & 7 & 7 & 7 \\
\hline 7. & Form Input Nilai & 5 & 5 & 3 \\
\hline 8. & Form Cetak Kelas & 3 & 3 & 4 \\
\hline 9. & Form Cetak Guru & 4 & 4 & 5 \\
\hline
\end{tabular}




\begin{tabular}{cllll}
\hline No. & Nama Bagan Alir Program & $\begin{array}{l}\text { Jumlah } \\
\text { CC }\end{array}$ & $\begin{array}{l}\text { Independent } \\
\text { Path }\end{array}$ & $\begin{array}{l}\text { Jumlah } \\
\text { Region }\end{array}$ \\
\hline 10. & Form Cetak Nilai & 4 & 4 & 4 \\
\hline 11. & Form Cetak Siswa & 4 & 4 & 4 \\
\hline 12. & Form Cetak Absensi & 3 & 3 & 3 \\
\hline \multicolumn{2}{c}{ Total } & 71 & 71 & 71 \\
\hline
\end{tabular}

Berdasarkan hasil pengujian program seperti yang terlihat pada Tabel 1, ternyata jumlah Region, Cyclomatic Complexity (CC) dan Independent Path adalah bernilai sama sehingga dapat ditarik kesimpulan bahwa sistem tersebut sudah benar. Dengan kata lain bahwa Informasi Akademik sekolah yang dibuat telah layak digunakan untuk menggantikan proses pelayanan yang sedang berjalan pada SMP Negeri I BUPON.

\section{KESIMPULAN}

Sistem pengolahan data yang dibuat merupakan informasi akademik yang menggunakan database. Desain akademik ini dapat membantu dalam proses pengolahan data siswa, guru, mata pelajaran dan nilai pada SMP Negeri I BUPON. Desain akademik tersebut sudah bebas dari kesalahan logika berdasarkan hasil pengujian dengan metode pengujian white box yakni jumlah Region $=71$, Cyclomatic Complexity $=71$ dan Independent Path $=71$ yang dihasilkan adalah sama.

\section{DAFTAR PUSTAKA}

Hartono, N., Paemboan, S \& Basmin, D. (2018), "Rancang Bangun Sistem Informasi Perpustakaan.", Jurnal Ilmiah d'Computare., Vol. 8.

Khan, M.E. (2010). "Different Forms of Software Testing Techniques for Finding Errors.", IJCSI International Journal of Computer Science Issues, Vol. 7(3), 11-16.

Nidhra, S., \& Jagruthi, D.(2012). "Black Box and White Box Testing Technique.", A Literature Review., Vol 2(2).

Pressman, R.S. (2010). Rekayasa Perangkat Lunak. Yogyakarta:Andi.

Sommerville I, (2003). Software Engineering (Rekayasa Perangkat Lunak) Jilid 2. Jakarta: Erlangga.

Syaikhuddin, M.M., Anam, C., Rinaldi, A.R \& Conoras, M.E.B.(2018).”Conventional Software Testing Using White Box Method.”, Kinetik., Vol. 3(1). 
PENA TEKNIK: Jurnal Ilmiah Ilmu-Ilmu Teknik

Volume 3, Nomor 2, September 2018 : 177 - 184

Halaman ini sengaja dikosongkan 